\title{
Antidiabetic Activity of Herbal Green Tea Extract from White Mangrove (Avicennia marina) Leaves towards Blood Glucose Level of Diabetic Wistar Rats (Rattus novergicus)
}

\author{
HARdoko $^{\mathrm{a}, \mathrm{b}^{*}}$, BintiNafi'Ah ${ }^{\mathrm{a}}$, Bambang B. SAsmito ${ }^{\mathrm{a}}$, And YuniwatyHalim ${ }^{\mathrm{b}}$ \\ ${ }^{\text {a }}$ Faculty of Fisheries and Marine Sciences, Universitas Brawijaya Jalan Veteran No. 1 Malang 65113, Indonesia

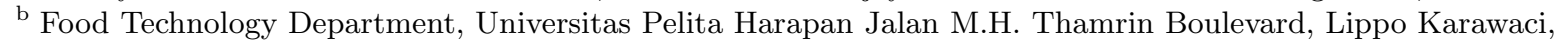 \\ Tangerang 15811, Indonesia \\ *Corresponding author \\ hardoko@ub.ac.id \\ TEL: +62-0341-553512 \\ FAx: $+62-0341-557837$
}

Received: 22 February 2018; Published online: 18 October 2019

\begin{abstract}
Green tea Camellia sinensis contains polyphenol that has antidiabetic activity. Mangrove leaves also contain polyphenol which potentially gives these leave antidiabetic activity. The aim of this research was to determine the ability of herbal green tea extract from white mangrove (Avicennia marina) leaves to decrease blood glucose level of diabetic Wistar rats (Rattus novergicus). The method used was experimental and involved giving a herbal green tea extract from white mangrove leaves with concentration of 100, 200 and $300 \mathrm{mg} / 200 \mathrm{~g} \mathrm{BW/day,} \mathrm{and} \mathrm{positive} \mathrm{control,} \mathrm{i.e.} \mathrm{glybenclamide} \mathrm{(0.09}$ $\mathrm{mg} / 200 \mathrm{~g} \mathrm{BW} /$ day), to diabetic rats injected with Streptozotocin (STZ) and Nicotinamide (NA). The rats were observed on day $0,5,10$ and 15 . The results showed that the herbal green tea extract from white mangrove leaves decreased the blood glucose level of diabetic rats. The effective extract dose that decreased the blood glucose level of diabetic rats was $300 \mathrm{mg} / 200 \mathrm{~g} \mathrm{BW}$, which is comparable to the effect produced by glybenclamide (antidiabetic medicine). This dose could decrease the blood glucose level of diabetic rats to reach a normal blood glucose level after 20 days.
\end{abstract}

Keywords: Diabetic; Extract; Blood glucose; Herbal mangrove green tea

\section{Introduction}

Diabetes mellitus is an endocrine condition that is caused by the decrease of insulin effectivity, i.e. a hormone that plays a role in the carbohydrate metabolism. Insufficient insulin secretion causes blood glucose level to exceed the normal acceptable physiological limit. Chronic high blood glucose levels causes nerve, blood vessel and coronary artery damage. In addition, this condition increases coronary disease risk, stroke, kidney failure and other disease complications (Fadilah, 2017).

Copyright (C)2019 ISEKI-Food Association (IFA)
Diabetic treatment generally involves dietary management and the use of synthetic chemical drugs or natural traditional medicine. The treatment using chemical drugs is considered less safe because of its unwanted side effects. Treatment using traditional medicine is considered safer because it has less side effects; therefore many diabetic patients are interested in it. One of the natural ingredients that can be used as a natural medicine is tea from $C$. sinensis leaves. Green tea is used to decrease obesity (Purwanto, Darmawati, Purwaningsih, \& Ners, 2014; Rahmanisa \& Wulandari, 2016; Sari, 2015), dia- 


\section{Nomenclature}

STZ Streptozotocin

NA Nicotinamide
BW Body Weight

GOD/PAP/POD Enzymatic colorimetric method betes (Bait, 2010; Cheng, Shen, \& Wu, 2009; Efendi, Damayanthi, Kustiyah, \& Kusumorini, 2010; Holidah, Yasmin, \& Christianty, 2018; Ilma, 2016; Rohdiana, Firmansyah, Setiawati, \& Yunita, 2012; Wibowo, Kusmana, Suryani, Hartati, \& Oktadiyani, 2009; Yilmazer-Musa, Griffith, Michels, Schneider, \& Frei, 2012); black tea to treat diabetes (Bait, 2010; Deswati \& Nur Maryam, 2017; Holidah et al., 2018; Rosalia, Indrasari, Tangsilan, Jayadi, \& Danu, 2017); white tea to treat diabetes (Trinoviani, Kholisoh, ArRifa, \& Rustamsyah, 2016) and kombucha green tea is used as a hepato protective agent. The role of tea in health is related to the presence of beneficial compounds such as polyphenol, theophylline, flavonoids, tannins, Vitamin $\mathrm{C}$ and $\mathrm{E}$, catechins and some minerals (Majid \& Nurkholis, 2010).

Considering the reported health benefits of tea people started brewing tea from leaves other than $C$. sinensis leaves, which is known as herbal tea. Some examples are, herbal tea from stevia leaves to treat diabetes (Trinoviani et al., 2016), mulberry leaves tea (Bait, 2010; Efendi et al., 2010), guava leaves herbal tea for diabetes (Cheng et al., 2009), stevia leaves tea for antioxidant (Ariviani \& Ishartani, 2009), avocado leaves' tea for antioxidant, soursop leaves' black tea for uric acid treatment (Hardoko, Puspitasari, \& Amalia, 2015), soursop leaves' extract to treat diabetes (Moniaga, 2014), soursop leaves' green tea to treat diabetes (Hardoko, 2015), fragrant pandan (Pandanus amaryllifolius Linn) leaves' water extract to treat diabetes (Prameswari \& Widjanarko, 2014). The roles of plants or products from plants as natural medicines are related to their bioactive compounds, which vary with the type of the plants.

Mangrove plant also has potential to be a natural medicine because it contains compounds, such as tannins, polyphenols, flavonoids, etc that in other plants and have been known as bioactive compounds. Other than their antioxidant capacity, compounds from the polyphenol group also play a role in improving glucose metabolism (Scalbert, Manach, Morand, Rémésy, \& Jimenez, 2005). Phenolic compounds have the ability to bind protein; therefore, the activity of $\alpha$-glucosidase activity can be inhibited (Rachmania, Supandi, \& Cristina, 2016). It has also the ability to trigger glucose metabolism by increasing tissue sensitivity towards insulin to prevent glucose accumulation in the blood (Prameswari \& Widjanarko, 2014). Of the many species of mangrove, the one that is dominant and widely available is white mangrove ( $A$. $m a$ rina). This mangrove contains high levels of alkaloids, saponin and glycosides (Wibowo et al., 2009). Based on this, white mangrove has high potential for development as a component of functional foods. To ease the consumption of white mangrove, its leaves can be processed into herbal tea and promoted as a health beverage especially in areas such as Indonesia and other geographical areas where tea is widely consumed. The brew of white mangrove leaves has brown colour, similar to tea, is easy to produce and should be acceptable alternative to tea drinkers. A previous research on white mangrove ( $A$. $m a$ rina) leaves characterized the flavonoid content that was used as an antioxidant agent (Handayani \& Nurjanah, 2013). The aim of this research was therefore to determine the ability of the green tea extract from white mangrove leaves 
to reduce the blood glucose level of diabetic Wistar rats ( $R$. norvegicus).

\section{Materials and Methods}

\subsection{Materials}

Herbal green tea extract from white mangrove (A. marina) leaves used, was obtained from 'UKM Tani Mangrove' at Rungkut Village, Wonorejo Subdistrict, Surabaya, Indonesia. 96\% ethanol (Merck, Germany) was used for extraction process, filter paper (Whatmann no.1) and label paper (brand: Tom\&Jerry).

Rat feeds were obtained from Centre for Food and Nutrition Research Laboratory (Gajah Mada University, Yogyakarta, Indonesia), these included corn flour, casein, sucrose, soybean oil, fiber, mineral mix AIN-93-MX/100 g of feed $\left(1 \mathrm{~g}\right.$ of $\mathrm{NaCl} ; 15 \mathrm{~g}$ of $\mathrm{MgSO}_{4} .7 \mathrm{H}_{2} \mathrm{O} ; 25$ $\mathrm{g}$ of $\mathrm{NaH}_{2} \mathrm{PO}_{4} .2 \mathrm{H}_{2} \mathrm{O} ; 32 \mathrm{~g}$ of $\mathrm{KH}_{2} \mathrm{PO}_{4} ; 20 \mathrm{~g}$ of $\mathrm{Ca}\left(\mathrm{H}_{2} \mathrm{PO}_{4}\right) .2 \mathrm{H}_{2} ; 2.5 \mathrm{~g}$ of Fecitrate (Kawano, Egashira, \& Sanada, 2007), vitamin mix AIN93-VX /100 g of feed (Thiamin $6 \mathrm{mg}$; Riboflavin $10 \mathrm{mg}$; Piridoxine $4 \mathrm{mg}$; Cyanocobalomine 0.01 mg; Vitamin C 500 mg; Niacin $40 \mathrm{mg}$; Capantothenate $10 \mathrm{mg}$; Inositol $200 \mathrm{mg}$; Biotin 0.6 mg; Folic acid $1.5 \mathrm{mg}$; R-amino benzoic acid 5 mg; Vitamin K3 5 mg; Vitamin A 4000 IU; Vitamin D3 4000 IU (Takeuchi, 1988)), L-Cystine, Choline bitartrate and Tert butylhydroquinone. Antidiabetic drug used as a positive control was glibenclamide $5 \mathrm{mg}$ (PT Kalbe Farma, Indonesia).

Streptozotocin (STZ) and nicotinamide (NA) (Nacalai Tesque, Kyoto) were used to condition rats with diabetes mellitus. Materials used for phytochemical analyses of herbal green tea extract were Magnesium, $2 \mathrm{~N} \mathrm{HCl}$, concentrated $\mathrm{H}_{2} \mathrm{SO}_{4}, 1 \% \mathrm{FeCl}_{3}$, sodium acetate anhydrous, chloroform, $\mathrm{HgCl}_{2}$, KI (Merck, Germany), aquadest (Hydrobatt) and label paper. Material used for blood glucose analysis was Glucose Kit GOD-PAP (Diasys, Germany).

3 -month old male wistar rats ( $R$. novergicus) with body weight of about 200 gram and their maintenance equipment, obtained from Centre for Food and Nutrition Research Laboratory (Gajah Mada University, Yogyakarta, Indonesia) were used for the experiments.

Equipment used for herbal green tea preparation included scissors, stove, balance (Kabuto 5000), basin, tray, steamer and baking pan.

Equipment used for herbal tea from mangrove leaves extraction were analytical balance (Mettler Toledo AB204-S), blender (Philips, Indonesia), $1000 \mathrm{ml}$ beaker glass (Pyrex), $250 \mathrm{ml}$ Erlenmeyer (Pyrex), $100 \mathrm{ml}$ measuring cylinder (Pyrex), spatula, funnel, spoon and rotary vacuum evaporator (Buchi R124).

Rats' blood was collected in Eppendorf tubes and haematocrit tubes andplaced on trays. Blood glucose level analysis required the use of a centrifuge (Sigma 3-18K), dropping pipettes, vortex mixer(VM-2000), reaction tubes (Schott Duran) and rack, micropipette (Accumax Pro 10$100 \mu \mathrm{L})$, spectrophotometer and micro cuvettes (Spectroquant Pharo 300).

\section{$2.2 \quad$ Research Methods}

Ethical clearance permission letter number 509KEP-UB was 'obtained from the Animal Care and Use Committee, Universitas Brawijaya, Malang, Indonesia. The experimental methods involved adminstering a dose of extract of green tea from white mangrove ( $A$. marina) leaves extract to diabetic rats, with negative control (rats that were fed with standard feeds) and positive control (diabetic rats that were given glybenclamide at a level of of $0.09 \mathrm{mg} / 200 \mathrm{~g}$ $\mathrm{BW} /$ day).The dosed rats were sampled at different times. The doses of green tea from white mangrove ( $A$. marina) leaves extract were administered orally at the following concentrations per unit body weight: $100 \mathrm{mg} / 200 \mathrm{~g}$ BW, 200 $\mathrm{mg} / 200 \mathrm{~g} \mathrm{BW}$ and $300 \mathrm{mg} / 200 \mathrm{~g} \mathrm{BW}$. The rats were fed for 15 days according to the treatments indicated and samples were taken for blood glucose determinations on day $0,5,10$ and 15 . The observed parameters were blood glucose level, body weight, the amount of feed consumption and feces weight. The experimental design used in this research was a randomized factorial design, followed by Duncan test. 


\section{Preparation of Herbal Green Tea Extract from White Mangrove Leaves (A. marina)}

Herbal green tea from white mangrove ( $A$. $m a-$ rina) was prepared from picked young mangrove (A. marina) that were cleaned and processed using steam, chopping and drying to obtain dry herbal green tea. Extraction was carried out using a maceration method with $96 \%$ ethanol as a solvent with a ratio of $1: 4(\mathrm{w} / \mathrm{v})$. This mixture was then put in a shaker for 6 hours and left at room temperature for 24 hours (12 hours dark and 12 hours light). The mixture was then filtered and the solvent was evaporated from the filtrate using a rotary evaporator at a temperature of $45^{\circ} \mathrm{C}$ until all the solvent has been evaporated. A thick extract was obtained that was ready for use in the experiment.

\section{Preparation of Diabetic Rats and Feeding of Herbal Green Tea Extract from Mangrove Leaves}

Male Wistar Rats (2.5-3 month old) were adapted for 7 days by putting each rat individually in a cage with sufficient light, ventilation, at room temperature under ad libitum standard feed and drink conditions, and weighed at the end of the adaptation phase. The rats were then induced with STZ (45 mg/200 g BW) and NA (110 mg/200 g BW) by intraperitoneal injection. After the diabetic condition was achieved, the rats were given several treatments: green tea extract from mangrove leaves of $100 \mathrm{mg} / 200$ g BW/day, $200 \mathrm{mg} / 200 \mathrm{~g} \mathrm{BW} /$ day and 300 $\mathrm{mg} / 200 \mathrm{~g} \mathrm{BW} /$ day using gavage needles, positive control (induced with glybenclamide with a dose of $0.09 \mathrm{mg} / 200 \mathrm{~g} \mathrm{BW} /$ day) and negative control (rats without any treatment). The experiment lasted for 15 days. On day 0, 5, 10 and 15, the rats' blood was collected from the orbital sinus and analysed for its blood glucose level.

\section{Qualitative Phytochemical Analyses}

Phytochemical analyses were based on methods used by Dia, Nurjanah, and Jacoeb (2015). Tannin analysis: $0.5 \mathrm{~g}$ of sample was put into a reaction tube to which was added $10 \mathrm{ml}$ of boiling aquadest, and then filtered. 3 drops of $1 \% \mathrm{FeCl}_{3}$, were added to the filtrate obtained. The presence of tannins was indicated by formation of brownish green colour or blackish blue colour.

Alkaloid analysis: $1 \mathrm{ml}$ of sample was put into a reaction tube to which 3 drops of Meyer reagent were added. These two solutions were mixed and diluted to $100 \mathrm{ml}$ ). A positive result was indicated by formation of yellowish white precipitate. Flavonoid analysis: To $0.05 \mathrm{~g}$ of sample were added the following: $0.1 \mathrm{mg}$ of Magnesium powder, $0.4 \mathrm{ml}$ of amyl alcohol (mixture of $37 \%$ hydrochloric acid and 95\% ethanol with the same volume) and $4 \mathrm{ml}$ of ethanol. The mixture was then shaken. The presence of flavonoid was indicated by formation of a red, yellow or orange colour in the amyl alcohol layer.

Steroid and terpenoid analysis: $0.5 \mathrm{~g}$ of sample was put into a reaction tube and to it added $10 \mathrm{ml}$ of boiling aquadest, the resulting mixture was then then filtered. The filtrate obtained was evaporated to dryness, and followed by the addition of the following reagents: $2 \mathrm{ml}$ of acetic acid glacial and $3 \mathrm{ml}$ of concentrated $\mathrm{H} 2 \mathrm{SO} 4$ to form layer. Formation of a blue-green colour indicated the presence of steroids, whereas the formation of reddish-purple indicates the presence of terpenoids.

Saponin analysis: $0.5 \mathrm{~g}$ of extract was diluted with $10 \mathrm{ml}$ of boiling aquadest, let cool and shaken manually for 30 second and changes that occur were observed. $2 \mathrm{~N} \mathrm{HCl}$ was dropped into the tube and changes that occur were also observed. If there is a solid foam formed (last for at least 30 seconds), then it indicates the presence of saponin.

\section{Blood Glucose Analysis}

Pre-prandial blood glucose was measured on day 0, 5, 10 and 15. The method used in this research was glucose the GOD-PAP method. This method involves the oxidation of glucose by gluco-oxidase (GOD) into gluconic acid and $\mathrm{H}_{2} \mathrm{O}_{2} \cdot \mathrm{H}_{2} \mathrm{O}_{2}$ was then reacted with phenol and 4aminoantipyrine to form chinonimine, which has red colour, and $\mathrm{H}_{2} \mathrm{O}$. This reaction was catalysed by peroxidase enzyme (POD). The chinonimine formed was equivalent to glucose, which 
means the colour measured from chinonimone was equivalent to the glucose level.

\section{Results and Discussion}

\subsection{Characteristics of Mangrove Green Tea Extract}

Mangrove green tea extract had a yield of $37.81 \%$, a moisture content of $6.46 \%$ and an ash content of $10.5 \%$. Yield was influenced by the initial moisture content and expected final moisture content (Hutami \& Harijono, 2014). Moreover, the moisture content of a product was influenced by the heating process and the initial moisture content (Pratama, Rostini, \& Liviawaty, 2014), whilst the ash content was influenced by the mineral content of the raw materials (Lestari \& Tjahjani, 2015).

Phytochemical analysis results showed that the mangrove (A. marina) green tea extract contained tannins, alkaloids, flavonoids and saponins. These compounds form part of the polyphenol group of compounds (Hardoko et al., 2015), which have antidiabetic and anti-uric acid activity (Hardoko, 2015).

\subsection{Preparation of Diabetic Rats}

Rats were declared diabetic when the increase in the blood glucose reached levels considered to demonstrate hyperglycaemia, i.e. increase of blood glucose level above the normal limit. The blood glucose level before and after induction with STZ and NA can be observed on Table 1. From Table 1, it can be seen that on day 0, before inducing using STZ, all rats had a normal blood glucose level, i.e. about 54-58 mg/dL. Normal blood glucose level of rats is about 50-135 $\mathrm{mg} / \mathrm{dL}$ (Johnson-Delaney, 1996). On day 3 after induced using STZ, all rats had an increase in blood glucose level to reach diabetes mellitus condition, except for control (-) rats. Rats are considered to be diabetic when the pre-prandial blood glucose level is above $126 \mathrm{mg} / \mathrm{dL}$ (Setiawan, 2012).

\subsection{The Effect of Herbal Mangrove Green Tea Extract on Blood Sugar Level of Diabetes Rats}

Anova results showed that treatment of duration and dose of mangrove green tea extract, and the interaction of both treatments, gave a significant effect on blood glucose level of diabetic rats $(\mathrm{p}<0.05)$. The post hoc test result using Duncan method can be seen on Figure 1.

From Figure 1, it can be inferred that the longer the feeding and the higher the dose of herbal mangrove green tea extract, the greater the decrease of blood glucose level on diabetic rats. This result may be due to the higher dose of extract that contains a higher concentration of bioactive compounds, which may have a greater effect on blood glucose level, compared to the lower dose of extract. It was presumed that tannins, flavonoids, alkaloids and saponins in herbal mangrove (A. marina) green tea extract play a role in reducing the blood glucose level on diabetic rats. Tannins consist of condensed tannins and hydrolysable tannins. Proanthocyanidins is the other name given to condensed tannins (Frutos, Hervás, Giráldez, \& Mantecón, 2004). There are several mechanisms of the effect of tannins ion the lowering of blood glucose levels, i.e. tannins decrease the blood sugar levels by inhibiting glucose absorption in intestines and tannins can induce the regeneration of pancreatic beta cells which cause adipose cells, to increase insulin activity (Kumari \& Jain, 2012). Moreover, an alkaloid extract has been proven to have the ability to increase the regeneration of damaged pancreatic beta cells (Arjadi \& Susatyo, 2010). The increase of insulin secretion is caused by a sympathetic nerve stimulation effect (sympathomimetic) by alkaloids. Saponins as an antidiabetic agent were described in previous research, in which after histopathologic examination of the pancreas, saponins could regenerate pancreas, so that the amount of pancreatic beta cells and islets of langerhans would increase, causing an increase in insulin secretion. The increase in insulin secretion could then decrease the blood glucose level (Firdous, Koneri, Sarvaraidu, Harish, \& Shubhapriya, 2009). 
Table 1: Blood glucose level of rats induced using STZ and NA

\begin{tabular}{ccc}
\hline & \multicolumn{2}{c}{ Blood Glucose Level (mg/dL) } \\
\cline { 2 - 3 } Treatment & $\begin{array}{c}\text { Before inducing using STZ } \\
(\text { day 0) }\end{array}$ & $\begin{array}{c}\text { After inducing using STZ } \\
(\text { day } 3)\end{array}$ \\
\hline Negative control & $54.68 \pm 1.08$ & $55.01 \pm 1.08$ \\
Positive control & $56.47 \pm 1.30$ & $221.91 \pm 1.32$ \\
$100 \mathrm{mg} / 200 \mathrm{~g} \mathrm{BW} /$ day & $58.39 \pm 1.10$ & $214.13 \pm 2.76$ \\
$200 \mathrm{mg} / 200 \mathrm{~g} \mathrm{BW} /$ day & $57.43 \pm 2.55$ & $210.95 \pm 5.21$ \\
$300 \mathrm{mg} / 200 \mathrm{~g} \mathrm{BW}$ /day & $57.79 \pm 0.75$ & $215.08 \pm 4.06$ \\
\hline
\end{tabular}

Table 2: Percentage of blood glucose level changes by herbal mangrove green tea extract

\begin{tabular}{cccccc}
\hline \multicolumn{5}{c}{ Blood glucose level changes } \\
\cline { 2 - 6 } Day & Negative control & Positive control & $100 \mathrm{mg} / 200 \mathrm{gBW}$ & $200 \mathrm{mg} / 200 \mathrm{gBW}$ & $300 \mathrm{mg} / 200 \mathrm{gBW}$ \\
\hline 5 & $+1.31 \%$ & $-14.02 \%$ & $-22.23 \%$ & $-22.23 \%$ & $-27.71 \%$ \\
10 & $+1.44 \%$ & $-38.34 \%$ & $-34.84 \%$ & $-38.34 \%$ & $-46.35 \%$ \\
15 & $+2.16 \%$ & $-55.39 \%$ & $-37.74 \%$ & $-42.37 \%$ & $-50.81 \%$ \\
\hline
\end{tabular}

Notes: $(+)=$ increase; $(-)=$ decrease

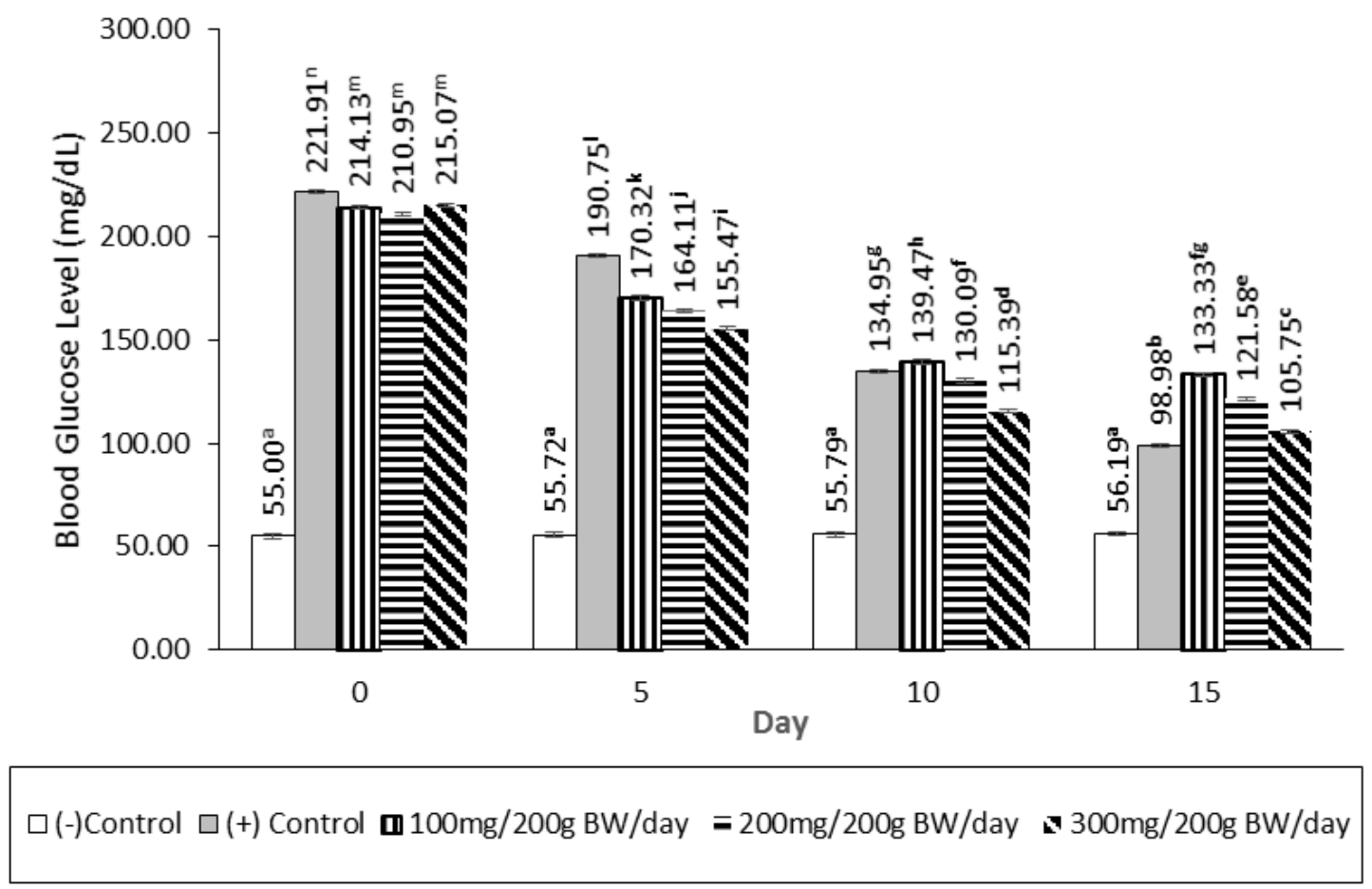

Figure 1: Histogram of blood glucose level of rats for 15 days. Notes: different superscript notation shows significant difference $(\mathrm{p}<0.05)$ 
Herbal green tea from white mangrove for antidiabetic 49

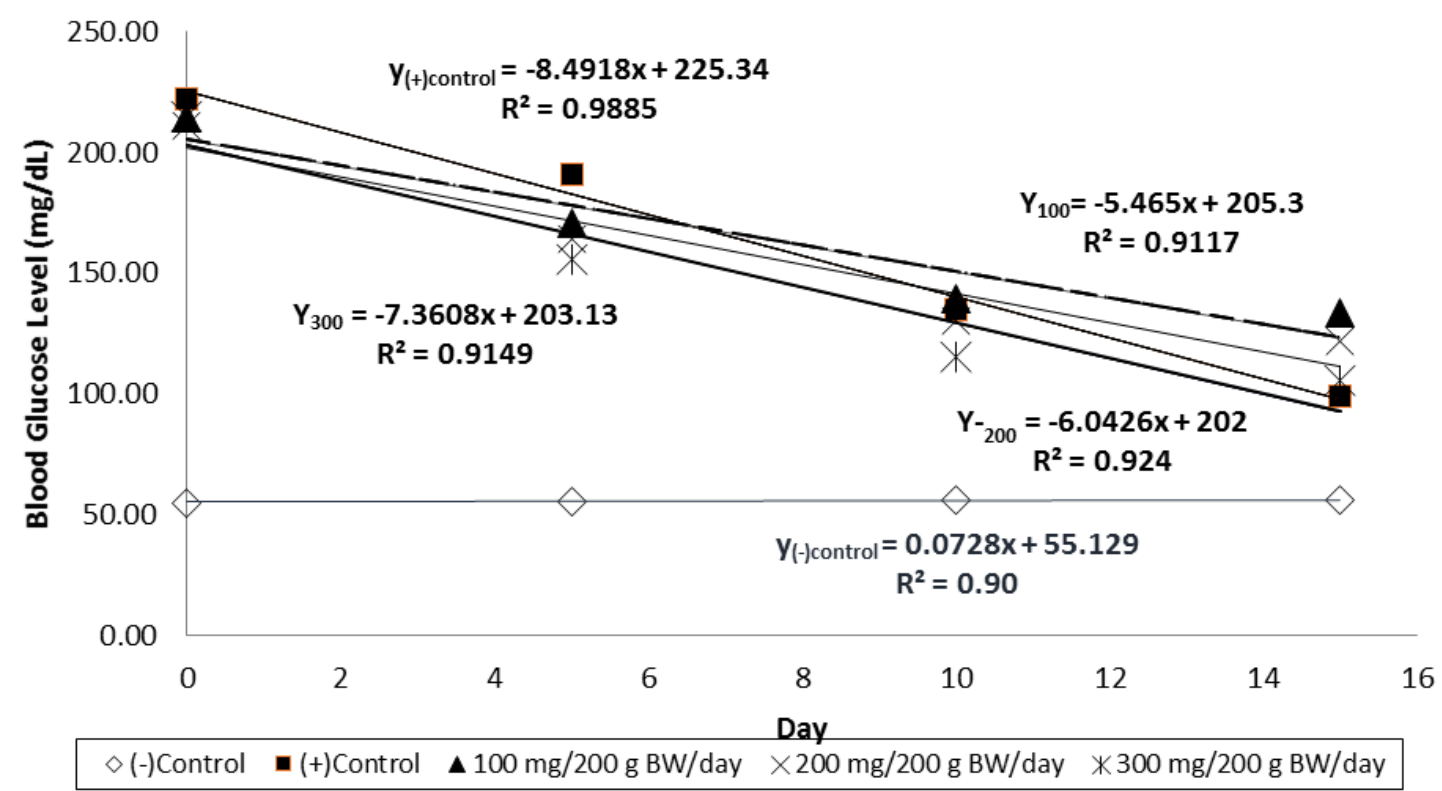

Figure 2: Linear regression of of rats' decreased blood glucose level

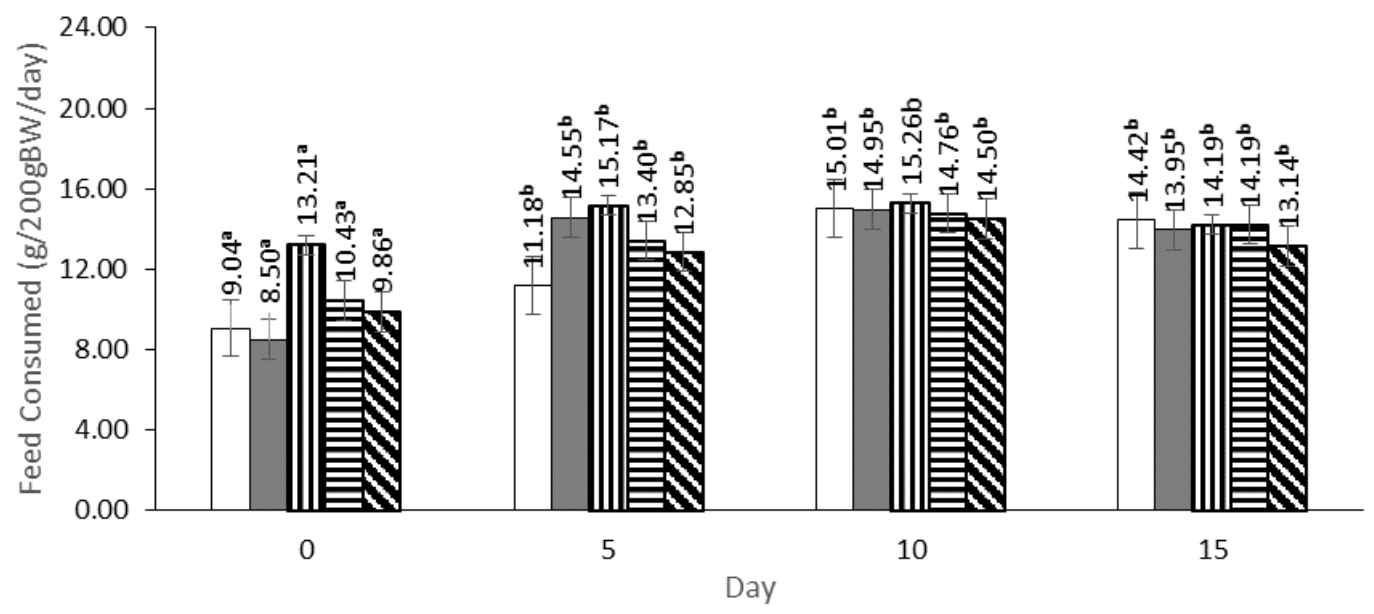

$\square(-)$ Control $\square(+)$ Control $\mathbf{m} 100 \mathrm{mg} / 200 \mathrm{~g}$ BW/day $\quad \boldsymbol{\square} 200 \mathrm{mg} / 200 \mathrm{~g}$ BW/day $\mathbf{\mathbf { v }} 300 \mathrm{mg} / 200 \mathrm{~g}$ BW/day

Figure 3: Histogram of the amount of feed consumed by rats during experiment. Notes: different superscript notation shows significant difference $(\mathrm{p}<0.05)$ 
To determine the effect of herbal white mangrove green tea extract on the blood glucose level, the calculation of the percentage of lowering of blood glucose is presented on Table 2. The higher the dose, the more effective the blood glucose levels decrease in diabetic rats. It is expected that because the bioactive compounds, which play a role in decreasing the blood glucose level, are different in each dose given, and there is also a difference in each rat's body response towards the dose given. The best dose of herbal mangrove green tea extract to decrease blood glucose level was $300 \mathrm{mg} / 200 \mathrm{~g} \mathrm{BW} /$ day, i.e. about $-50.81 \%$. To predict on which day the herbal mangrove green tea extract feeding could decrease the diabetic blood glucose level to the normal blood glucose level, a linear regression that shows the correlation of blood glucose level and the dose of extract given was constructed (Figure 2). The intersection of the regression equation of negative control and extract dose shows the day on which the blood glucose level of diabetic rats decrease to normal. The day on which blood glucose level of diabetic rats decreases to normal can also be calculated by changing the $\mathrm{Y}$-axis value with blood glucose level of control negative rats, i.e. $55.675 \pm 1.30 \mathrm{mg} / \mathrm{dL}$.

The results based on the regression equation shows that the blood glucose level of positive control rats are normal at day 20, rats treated with an extract dose of $100 \mathrm{mg} / 200 \mathrm{~g} \mathrm{BW} /$ day are normal on day 28 , rats treated with an extract dose of $200 \mathrm{mg} / 200 \mathrm{~g} \mathrm{BW} /$ day are normal on day 24 and rats treated with an extract dose of $300 \mathrm{mg} / 200 \mathrm{~g} \mathrm{BW} /$ day are normal on day 20 . Thus, the dose of herbal mangrove green tea extract that is comparable to glybenclamide $(0.09$ $\mathrm{mg} / 200 \mathrm{~g} \mathrm{BW} /$ day) was $300 \mathrm{mg} / 200 \mathrm{~g} \mathrm{BW} /$ day.

\subsection{Amount of Feed Consumed by Rats}

The amount of feed consumed by rats was determined by counting the difference between the amount of feed given and the remaining feed, which was not consumed by the rats. Anova statistical result shows that the duration gave a significant effect on the amount of feed consumed $(\mathrm{p}<0.05)$, whereas the extract dose and the in- teraction of both did not give a significant effect on the amount of feed consumed ( $p>0.05)$. Post hoc test result using Duncan method can be seen in Figure 3.

The amount of feed consumed could influence blood glucose level of rats (Wahyu, 2004). However, in this research, the amount of feed consumed on the same day of observation was not significantly different (Figure 3). This implies that the decrease in blood glucose level of rats was only affected by the herbal mangrove green tea extract given. The other factors that could influence the amount of feed consumed are palatability, appetite, environmental conditions and in case of illness (Wahyu, 2004).

\section{Conclusions}

Supplementation of herbal white mangrove $(A$. marina) green tea extract for 15 days could decrease the blood glucose level of diabetic Wistar rats ( $R$. novergicus).

The effective dose of herbal white mangrove (A. marina) green tea extract in decreasing the blood glucose level on diabetic Wistar rats (R.novergicus) is $300 \mathrm{mg} / 200 \mathrm{~g} \mathrm{BW} /$ day, which is comparable to glybenclamide.

\section{References}

Ariviani, S., \& Ishartani, D. (2009). Formulasi teh herba manis (teh hijau-stevia-herba): Organoleptik, antioksidan dan total kalori. Jurnal Teknologi Hasil Pertanian, 2(2), 78-86.

Arjadi, F., \& Susatyo, P. (2010). Regenerasi sel pulau langerhans pada tikus putih (rattus norvegicus) diabetes yang diberi rebusan daging mahkota (phaleria macrocarp lam). Sains Medika, 2(2), 117-126.

Bait, Y. (2010). Efektivitas pemberian seduhan teh hitam, teh hijau (camelia sinensis var. assamica), teh daun murbei (morus kanva) dan campurannya dalam aktivitas hipoglikemik pada tikus (rattus norvegicus) diabetes. Diabetes. Institut Pertanian Bogor. Retrieved from https://repository.ipb.ac. id/handle/123456789/41341 
Cheng, F.-C., Shen, S.-C., \& Wu, J. S.-B. (2009). Effect of guava (psidium guajava l.) leaf extract on glucose uptake in rat hepatocytes. Journal of Food Science, $74(5)$, H132-H138. doi:10.1111/j.1750-3841.2009. 01149.x. eprint: https://onlinelibrary.wiley. com/doi/pdf/10.1111/j.1750-3841.2009. 01149.x

Deswati, A. D., \& Nur Maryam, Z. (2017). Antidiabetic mellitus activity of low grade black tea in alloxan induced male albino mice. Jurnal Penelitian Teh dan Kina, 19(2), 208-214. doi:10.22302 / pptk. jur . jptk.v19i2.121

Dia, S. P. S., Nurjanah, N., \& Jacoeb, A. M. (2015). Chemical composition, bioactive components and antioxidant activities from root, bark and leaf lindur. Jurnal Pengolahan Hasil Perikanan Indonesia, 18(2).

Efendi, R., Damayanthi, E., Kustiyah, L., \& Kusumorini, N. (2010). Pengendalian kadar glukosa darah oleh teh hijau dan atau teh daun murbei pada tikus diabetes. Jurnal Gizi dan Pangan, 5, 87. doi:10 . 25182/jgp.2010.5.2.87-94

Fadilah, N. (2017). Uji total fenol dan daya inhibisi enzim alpha-glukosidase kayu manis (cinnamomum burmanii ness. ex blume.) secara soxhletasi (Doctoral dissertation, Widya Mandala Catholic University Surabaya). Retrieved from http:// repository. wima. ac .id / 12163 / 6 / BAB \% 5C\%205.pdf

Firdous, M., Koneri, R., Sarvaraidu, C. H., Harish, M., \& Shubhapriya, K. H. (2009). Niddm antidiabetic activity of saponins of momordica cymbalaria in streptozotocinnicotinamide niddm mice. Journal of Clinical and Diagnostic Research, 3(2), 14601465.

Frutos, P., Hervás, G., Giráldez, F., \& Mantecón, A. (2004). Review. tannins and ruminant nutrition. Spanish Journal of Agricultural Research, 2. doi:10.5424/sjar/2004022-73

Handayani, S., \& Nurjanah, S. R. (2013). Kandungan flavonoid kulit batang dan daun pohon api-api (avicennia marina (forks.) vierh.) sebagai senyawa aktif antioksidan. Bogor. Fakultas Perikanan dan Ilmu Kelautan Institut Pertanian Bogor. Skripsi,
35-37. Retrieved from http:// repository. ipb.ac.id/handle/123456789/61383

Hardoko, H. (2015). In vitro anti-gout activity and phenolic content of "black tea" soursop annona muricata l. leaves brew. Journal of Chemical and Pharmaceutical Research, 2015, 735-743.

Hardoko, S. E., Puspitasari, Y. E., \& Amalia, R. (2015). Study of ripe rhizophora mucronata fruit flour as functional food for antidiabetic. International Food Research Journal, 22(3), 953-959.

Holidah, D., Yasmin, Y., \& Christianty, F. M. (2018). Uji aktivitas antidiabetes ekstrak teh hitam dan teh hijau secara in vitro menggunakan metode inhibisi enzim alphaglukosidase (in vitro antidiabetic activity of black tea and green tea extracts by inhibition of alpha-glucosidase method). Pustaka Kesehatan, 6(2), 235-239.

Hutami, F. D., \& Harijono, H. (2014). Pengaruh penggantian larutan dan konsentrasi nahco3 terhadap penurunan kadar sianida pada pengolahan tepung ubi kayu [in press oktober 2014]. Jurnal Pangan dan Agroindustri, 2(4), 220-230.

Ilma, W. Z. (2016). Pengaruh pemberian ekstrak teh hijau (camellia sinensis l.) terhadap kadar glukosa darah dan gambaran histopatologi hepar mencit diabetes yang diinduksi aloksan. Retrieved from http:// repository. unej. ac.id / handle/123456789/ 78294.

Johnson-Delaney, C. (1996). Exotic animal companion medicine handbook for veterinarians. Lake Worth (FL): Zoological Education Network, 1-15.

Kawano, N., Egashira, Y., \& Sanada, H. (2007). Effect of dietary fiber in edible seaweeds on the development of d-galactosamineinduced hepatopathy in rats. Journal of nutritional science and vitaminology, 53(5), 446-450. doi:10.3177/jnsv.53.446

Kumari, M., \& Jain, S. (2012). Tannin: An antinutrient with positive effect to manage diabetes. Research Journal of Recent Sciences, Vol I.

Lestari, A. P., \& Tjahjani, S. (2015). Pemanfaatan bungkil biji kapuk (ceiba pentandra) sebagai campuranbriket sekam padithe uti- 
lization of cotton seed meal (ceiba pentandra) as a mixture ofa rice husk briquette. UNESA Journal of Chemistry, 4(1). Retrieved from http://ejournal.unesa.ac.id/ index ·php / unesa - journal - of - chemistry / article/view/11061

Majid, N. T., \& Nurkholis, N. (2010). Low caffeine of tea production through the extraction process with ethyl acetate solvent (thesis). Retrieved from http://eprints.undip. ac.id $/ 22787$

Moniaga, F. S. (2014). Pengaruh pemberian ekstrak daun sirsak (annona muricata 1.) terhadap kadar gula darah tikus wistar (rattus norvegicus) yang diinduksi alloxan. Jurnal e-Biomedik, 2(1), 1-7. doi:10.35790/ebm. 2.1.2014.3645

Prameswari, O. M., \& Widjanarko, S. B. (2014). The effect of water extract of pandan wangi leaf to decrease blood glucose levels and pancreas histopathology at diabetes mellitus rats. Jurnal Pangan Dan Agroindustri, 2(2), 16-27.

Pratama, R. I., Rostini, I., \& Liviawaty, E. (2014). Karakteristik biskuit dengan penambahan tepung tulang ikan jangilus (istiophorus sp.) Jurnal Akuatika, 5(1).

Purwanto, D., Darmawati, A., Purwaningsih, \& Ners, J. (2014). Efek teh hijau terhadap peningkatan fluiditas darah dan penurunan berat badan (the impact of green tea on blood fluidity improvement and weight loss). Jurnal Ners, 9(1), 1-5.

Rachmania, R. A., Supandi, S., \& Cristina, F. A. D. (2016). Analisis penambatan molekul senyawa flavonoid buah mahkota dewa (phaleria macrocarpa (scheff.) boerl.) pada reseptor alpha-glukosidase sebagai antidiabetes. Pharmacy: Jurnal Farmasi Indonesia (pharmaceutical Journal of Indonesia), 13(02).

Rahmanisa, S., \& Wulandari, R. (2016). Pengaruh ekstrak teh hijau terhadap penurunan berat badan pada remaja. Jurnal Majority, 5(2), 106-111.

Rohdiana, D., Firmansyah, A., Setiawati, A., \& Yunita, N. (2012). Antidiabetic activity of of green tea ethanol extract on white mouse. Jurnal Penelitian Teh dan Kina, $15(1)$.
Rosalia, A. A., Indrasari, M. C., Tangsilan, M. A., Jayadi, T., \& Danu, S. S. (2017). Pengaruh infusa teh hitam (camelia sinensis) terhadap gambaran histopatologi hepar, renal dan jumlah sel-sel alfa dan beta pankreas tikus jantan spraguedawley diinduksi etanol 20\%. Berkala Ilmiah Kedokteran Duta Wacana, 2(1), 243. doi:10. 21460/bikdw.v2i1.36

Sari, M. A. (2015). Aktivitas antioksidan teh daun alpukat (persea americana mill) dengan variasi teknik dan lama pengeringan (Doctoral dissertation, Universitas Muhammadiyah Surakarta). Retrieved from http://eprints.ums.ac.id/32865/

Scalbert, A., Manach, C., Morand, C., Rémésy, C., \& Jimenez, L. (2005). Dietary polyphenols and the prevention of diseases. Critical reviews in food science and nutrition, 45, 287-306. doi:10.1080/1040869059096

Setiawan, M. (2012). Pre-diabetes dan peran hba1c dalam skrining dan diagnosis awal diabetes melitus. Saintika Medika: Jurnal Ilmu Kesehatan dan Kedokteran Keluarga, $7(1)$.

Trinoviani, E., Kholisoh, A., Ar-Rifa, N. F., \& Rustamsyah, A. (2016). Inhibition activity of $+/$-glucosidase by infusion and ethanol extract of white tea and stevia combination. Jurnal Penelitian Teh dan Kina, 19(2), 202-207.

Wahyu, J. (2004). Ilmu nutrisi ternak unggas. Gajah Mada University Press. Yogyakarta.

Wibowo, C., Kusmana, C., Suryani, A., Hartati, Y., \& Oktadiyani, P. (2009). Pemanfaatan pohon mangrove api-api (avicennia spp.) sebagai bahan pangan dan obat. In Di dalam: Prosiding seminar hasil-hasil penelitian ipb. Retrieved from http: / / repository.ipb.ac.id/handle/123456789 / 71604

Yilmazer-Musa, M., Griffith, A. M., Michels, A. J., Schneider, E., \& Frei, B. (2012). Grape seed and tea extracts and catechin 3-gallates are potent inhibitors of alpha-amylase and alpha-glucosidase activity. Journal of Agricultural and Food Chemistry, 60(36), 8924-8929. PMID: 22697360. doi:10.1021/jf301147n 